\title{
Cardioprotective Effects of Exogenous and Endogenous Hydrocortisone in the Rabbit Model of Ischemia-Reperfusion
}

\author{
Efectos Cardioprotectores de la Hidrocortisona Exógena \\ y Endógena en el Modelo Isquemia-Reperfusión de Conejo
}

*Ali Davarian; ${ }^{* *}$ Vahid Khori $\&{ }^{* * * *}$ Mohsen Nayebpour

DAVARIAN, A.; KHORI, V. \& NAYEBPOUR, M. Cardioprotective effects of exogenous and endogenous hydrocortisone in the rabbit model of ischemia-reperfusion. Int. J. Morphol., 28(3):653-658, 2010.

SUMMARY: Reducing the infarct size in acute myocardial infarction is one of the most important goals driving new drug research and development. During the last two decades, many clinical studies have found cardioprotective effects of corticosteroids, but their exact role in ischemic preconditioning remains questionable. The aim of the present study was to determine the protective effects of hydrocortisone sodium succinate on myocardial preconditioning in rabbit hearts. Twenty-four male New Zealand rabbits were divided randomly \& equally in four groups: 1) control, 2) Infarct, 3) Ischemic preconditioning (IP) and 4) Hydrocortisone (HYD). The HYD group received 50mg/kg Hydrocortisone 45min before major ischemia. Serum levels of cardiac troponin-T(cTNT) and cortisole were measured before and after the protocols. Triphenyl-tetrazolium chloride staining was used to determine the infarcted area. In the present study, exogenous hydrocortisone decreased infarct size by $53 \%$ in comparison to the infarct group. Serum level of cortisole was increased in the IP and HYD groups, and was significant in the HYD group $(\mathrm{p}<0.01)$. An increasing trend in cortisole level was associated with a decreasing trend in infarct size and cTNT in the IP and HYD groups $(\mathrm{p}>0.01)$. In conclusion, we showed that hydrocortisone has cardioprotective effects when injected before the onset of myocardial infarction. In addition, we have proposed for the first time that endogenous hydrocortisone may play a role in ischemic preconditioning phenomena.

KEY WORDS: Hydrocortisone; Infarct size; Ischemia-reperfusion model; Ischemic preconditioning; Serum cortisole.

\section{INTRODUCTION}

Many studies have focused on finding new ways to reduce the size of an infracted myocardium after AMI, one of the major causes of mortality and morbidity in the Western world (Zipes \& Braunwald, 2005). In the past two decades, a new phenomenon called "Ischemic Preconditioning (IP)" has aroused great interest as a method for treating AMI. The discovery of many endogenous peptides in the IP pathway has opened up a new perspective for pharmacologic preconditioning by various types of drugs (Eisen et al., 2004; Werns \& Lucchesi, 1989).

Some studies have found protective effects of corticosteroids such as dexamethasone and methylprednisolone, when administered after coronary artery occlusion (HafeziMoghadam et al., 2002; Maclean et al., 1978; Fillinger et al., 2002; Enc et al., 2006). The later phase of myocardial cell injury, in part, results from acute inflammatory reactions ensuing in the ischemic myocardium, as infarct size can be effectively reduced by anti-inflammatory agents (Fu et al., 2007; Gross et al., 2004; Cannon et al., 2004). Despite numerous clinical and some experimental studies regarding the effects of corticosteroids in reducing myocardial infarct size (Libby et al., 1973; Hepper et al., 1955; Kilger et al., 2003; Giugliano et al., 2003), their role in IP phenomena remains open to debate. For example, corticosteroids given as late as $6 \mathrm{~h}$ after coronary occlusion can reduce infarct size by up to $35 \%$ in comparison with an untreated control group (Park \& Lucchesi, 1999).

Our postulate is that an increase in endogenous hydrocortisone is correlated with a decrease in infarct size. Our working hypotheses are that injection of exogenous hydrocortisone before major ischemia will reduce infarct size; and also that endogenous hydrocortisone is responsible for the effects of IP in reducing infarct size.

* Golestan Cardiovascular Research Centre, Faculty of Medicine, Golestan University of Medical Sciences, Gorgan, Iran.

** Associate Professor, Golestan Cardiovascular Research Centre, Faculty of Medicine,Golestan University of Medical Sciences, Gorgan, Iran.

*** Associate Professor, Faculty of Pharmacy, Department of Pharmacology and Toxicology, Tehran University of Medical Science, Iran. 
Therefore, this study was conducted to assess "Cardioprotective effects of exogenous and endogenous hydrocortisone in a rabbit model of ischemia-reperfusion".

\section{MATERIAL AND METHOD}

This study was approved by the Institutional Animal Care and Use Committee of the Golestan University of Medical Sciences and was performed in accordance with the "Guide for the Care and Use of Laboratory Animals" from National Institutes of Health (NIH Publication No. 8613, Revised 1996).

Animals. Male New Zealand rabbits, weighing $1.5-2.5 \mathrm{~kg}$ (purchased from "Iranian Pasteur Institute", Tehran, Iran) were used. Rabbits were kept in an animal house, with food and water available ad libitum, under a $12 \mathrm{~h}$ light-dark cycle and controlled temperature $\left(22 \pm 2^{\circ} \mathrm{C}\right)$.

Experimental Design. All 24 rabbits used in this study were divided randomly and equally into four experimental groups: 1-Control ( $\mathrm{n}=6$ ), 2-Infarct $(\mathrm{n}=6), 3$-Ischemic preconditioning

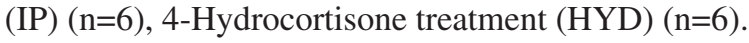

General anesthesia was induced by injection of Ketamine $(50 \mathrm{mg} / \mathrm{kg}$ ) and Xylazine $(5 \mathrm{mg} / \mathrm{kg})$ intramuscularly and maintained by intravenous (IV) injection of this mixture. Rabbits were intubated and attached to an animal ventilator (UGO Basile, Italy) and ventilated to receive $\mathrm{SPO}>95 \%$. In order to induce myocardial ischemia among all groups except the control, after left thoracotomy, the left anterior descending (LAD) coronary artery was ligated by a 3-0 silk suture for $45 \mathrm{~min}$. This was followed by a $120 \mathrm{~min}$ reperfusion after loosening the snare.

In the IP group, three cycles of $5 \mathrm{~min}$ ischemia were followed by $10 \mathrm{~min}$ reperfusion before major ischemia. The HYD group received $50 \mathrm{mg} / \mathrm{kg}$ Hydrocortisone sodium succinate (ROTEXMEDICA, Germany) by IV, $45 \mathrm{~min}$ before major ischemia. At the end of reperfusion, Evans blue dye (4\%) was injected IV and hearts were removed and cut into $4 \mathrm{~mm}$ thick slices. After staining with Triphenyltetrazoliumchloride (1\%) for 20 minutes, the tissues were fixed with buffered formaldehyde solution for another 24 hours, to determine the infarcted area (IA) and Area At Risk (AAR).

Analytical procedures. ECG monitoring from lead II and SPO2 monitoring (POWERLAB®, Australia) were performed throughout the operation time. Blood samples were taken before and after operation for measurement of serum levels of cortisole and Cardiac Troponin- T (cTNT). Statistical analysis. All results are presented as the mean \pm SEM. Means of groups were compared by one-way analysis of variance (ANOVA), and then post hoc analysis (LSD test) was performed for specific group comparisons. In order to test the correlation between cTNT-2 and IA Volume and IA/AAR ratio, Pearson Linear Correlation was used. The level of statistical significance was accepted as $\mathrm{p}<0.05$. Calculations were performed using SPSS software version 11.5 (SPSS, Chicago, IL, USA).

\section{RESULTS}

ST-segment. The increase of ST-segment elevation after LAD ligation in the Infarct group was more than that of the IP or HYD groups (Fig. 1). The increase among the IP group was significantly less $(\mathrm{p}<0.001)$. Although the increment in this value in the HYD group was less than in the Infarct group, it was not statistically significant ( $p>0.05$ ). In addition, by comparing the percentage of decrement in ST-segment elevation after 60 minutes of reperfusion, it was found that the HYD group showed a more significant effect than did the IP group $(\mathrm{p}<0.05)$.

Myocardial Infarct size. As shown in Fig. 2, the Infarcted Area (IA) as well as the Infarcted Area Volume (IA Volume) were decreased in both the IP and HYD groups and these decrements were statistically different when compared to those of the Infarct group ( $<0.0001$ for both). However, there were no statistically significant differences between the IP and HYD groups in terms of the amount of decrease in either IA and IA volume ( $p>0.05$ ). These findings revealed a significant decrease in the ratio of IA/AAR among IP and HYD groups in comparison to the Infarct group $(p<0.05$ in IP vs. Infarct and $p<0.001$ in HYD vs. control). It is notable that the decrement in the HYD group was larger than the IP group but was not statistically significant (p>0.05) (Fig. 2).

Serum levels of cTNT. The levels of cTNT were increased from an undetectable level $(\mathrm{p}<0.01 \mathrm{ng} / \mathrm{ml})$ to detectable amounts among all groups except the control. We also found a decrease in cTNT levels after surgery among the IP and HYD groups in comparison to the Infarct group, which was more prominent in HYD group (Fig. 3). Despite all of this, there were no statistically significant differences between the IP or HYD groups and the Infarct group or even between IP and PP groups ( $\mathrm{p}>0.05$ ) (Fig .3).

Alterations in Serum Levels of Cortisole. There were no significant differences among serum levels of cortisole before the onset of surgery between groups ( $p>0.05$ ). As shown in 


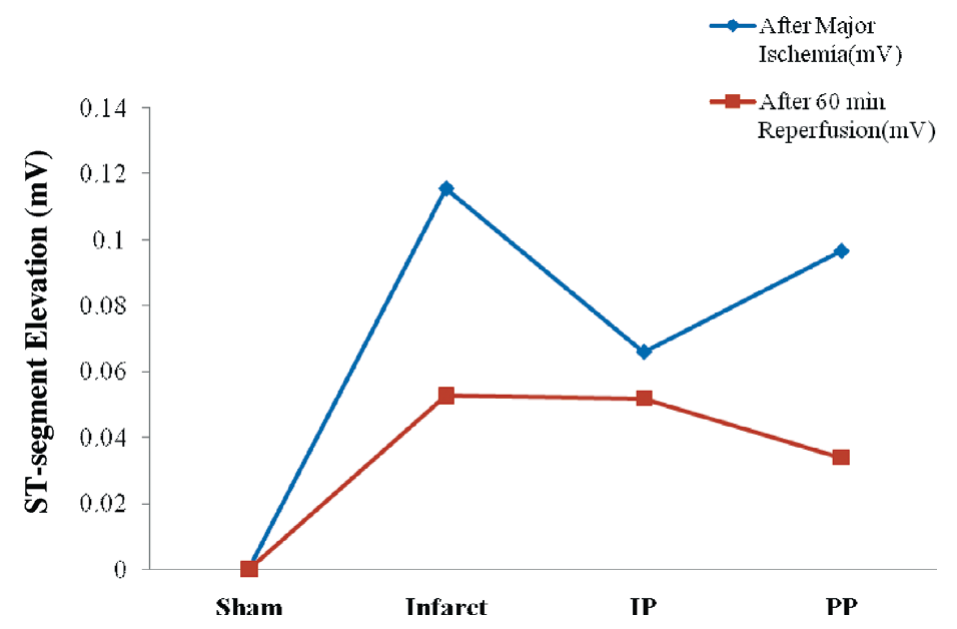

Fig. 1. The trend in ST-segment elevation in experimental groups before major ischemia and 60 min after onset of reperfusion. IP=Ischemic Preconditioning, $\mathrm{PP}=\mathrm{Pharmacologic}$ preconditioning, Data are expressed as the mean $\pm \mathrm{SEM}$.

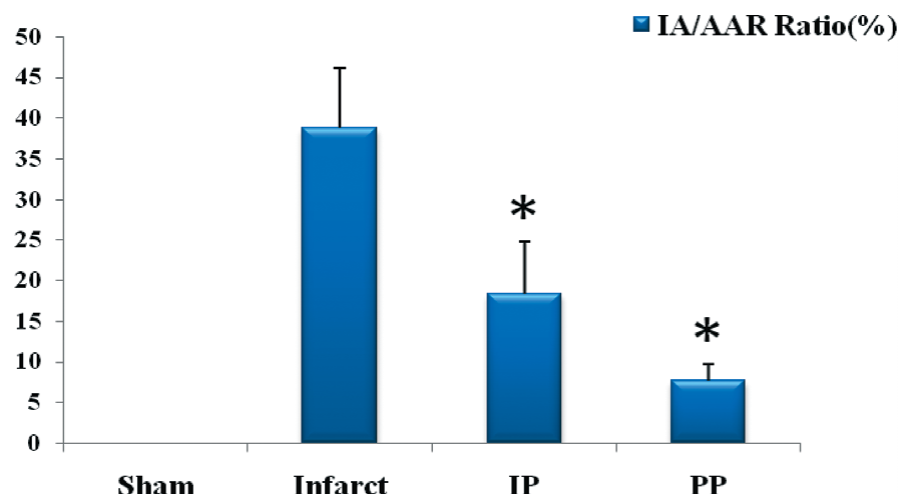

Fig. 2. Planimetry of Myocardial tissue showing Infarcted Area /Area At Risk ratio (IA/AAR Ratio); IP=Ischemic Preconditioning, PP=Pharmacologic preconditioning;=Standard Error of Mean. *=significantly difference in comparison to control group $(\mathrm{P}=0.05)$. Data are expressed as the mean $\pm \mathrm{SEM}$.

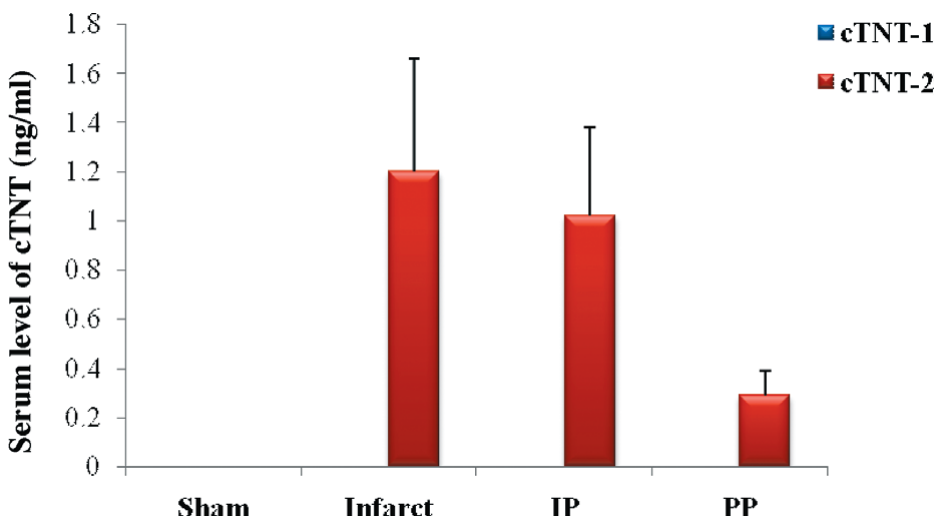

Fig. 3. Serum level of cardiac troponin-T (cTNT), before the onset of surgery (cTNT-1) and after the end of reperfusion(cTNT-2). IP=Ischemic Preconditioning, $\mathrm{PP}=$ Pharmacologic preconditioning,=Standard Error of Mean. There were no significant differences between groups. Data are expressed as the mean \pm SEM.
Fig. 4, an increase of serum levels of cortisole was seen after the surgical process which had been performed on all groups. However, the increase in serum cortisole levels were greater in the IP and HYD groups than in the Infarct group in comparison to the levels before surgery in each group, but this increment was only statistically significant in the HYD group in comparison to the Infarct group ( $\mathrm{p}<0.05)$.

\section{DISCUSSION}

The results of this study reveal that exogenous hydrocortisone may provide a protective effect in reducing the size of a myocardial infarct in the "Rabbit heart model of Ischemia-reperfusion". This cardioprotective effect was associated with a decreased Cardiac Troponin-T (cTNT), ST-Segment, Infarct Area (IA), Volume of Infarct Area and Infarcted area to Area At risk ratio (IA/AAR).

The ability of hydrocortisone to reduce infarct size in our study was in agreement with other studies on glucocorticoids (Maclean et al.; Kilger et al.; Johnson et al., 1953; Hepper et al.; Barzilai et al., 1972), but with a difference in that hydrocortisone in our study was more effective than were the recent widely-used synthetic analogues of corticosteroids, dexamethasone and methylprednisolone (Hafezi-Moghadam et al.; Enc et al.; Bourbon et al., 2004). In the study by Hafezi-Moghadam et al., dexamethasone reduced infarct size by about $36.5 \%$, while in our study hydrocortisone produced about a 53\% decrease, or a nearly 1.5 fold greater effect than that observed with dexamethasone. With the use of salvaged myocardium as an index of cardioprotective efficacy, Maclean et al found hydrocortisone to be more effective in comparison to methylprednisolone (Maclean et al.), in agreement with our results.

In other studies, the stimulation of a Glucocorticoid Receptor (GR) has been found responsible for the decreased inflammatory response and increased protective effects in reducing the infarct size by synthetic analogues of corticosteroids without high mineralocorticoid potency (such as 


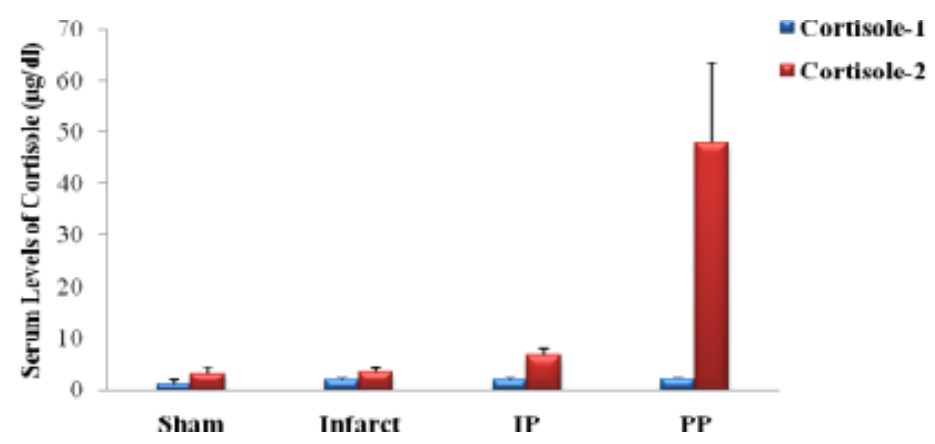

Fig. 4. Serum Level of Cortisole before the onset of surgery (Cortisole-1) and after the end of reperfusion(cortisole-2). IP=Ischemic Preconditioning, $\mathrm{PP}=$ Pharmacologic preconditioning; Data are expressed as the mean $\pm \mathrm{SEM}$.

Methylprednisolone and Dexamethasone) (Hafezi-Moghadam et al.; Fillinger et al.; Bourbon et al.). Many studies have demonstrated that myocardial tissue is capable of secreting glucoco- and mineralocorticosteroids; as well, Mineralocorticoid Receptors (MR) and an adrenal corticosteroid synthetase enzyme have been found in myocardial tissue (Gómez-Sanchez \& Gómez-Sanchez, 2001; White, 2003). In addition, the mineralocorticosteroid antagonist, spironolactone, was shown to have deleterious consequences on the protective effect of aldosterone in ischemia-reperfusion injury in cultured rat cardiac fibroblasts (White). On the other hand, it is notable that natural glucocorticoids, such as hydrocortisone, have ten times more affinity for binding to MR than do other synthetic analogues (Sapolsky et al., 2000). These findings emphasize that cardioprotective effects of corticosteroids are not related to their anti-inflammatory or glucocorticoid actions; thus, these may be due to their mineralocorticoid properties. In this case, these findings are in agreement with our study finding which emphasises that hydrocortisone efficacy is greater than other corticosteroid synthetic analogues.

Recently, it has been shown that synthetic corticosteroid derivatives that lack anti-inflammatory and glucocorticoid effects (Lazaroids) still have a substantial cardioprotective role. The major mechanism of these agents is free radical scavenging (Takahashi et al., 1998; Villa \& Gorini, 1997), which implies that at least some portion of the effects of cortisole are mediated by a different mechanism. Another important finding of our study was the correlation between the increment of endogenous cortisole and decrease of the infarct size among the Infarct and IP Groups. Many studies have been done to clarify the exact mechanism of ischemic preconditioning, and have found that many endogenous factors such as adenosine, nitric oxide, nuclear factors and ATP-dependent potassium channels are involved in this phenomenon (Lochner et al., 1998; Lochner et al., 2002; Armstrong et al., 2001). However, until now, there have been no studies on the role of hydrocortisone in ischemic preconditioning.

Munck et al. presented a model of glucocorticoid action that includes stimulatory and suppressive effects of glucocorticoids on endogenous stress responses. The model describes a bell-shaped curve, with cortisole exerting stimulatory effects at lower levels up to approximately 20 to $25 \mathrm{mg} / \mathrm{dL}$, whereas at higher levels, suppressive glucocorticoid effects become more prominent (Fillinger et al.). It has also been proposed that natural glucocorticoids have ten times more affinity for the Mineralocorticoid Receptor that is responsible for the permissive effects of glucocorticoids, and we know that during the permissive action of glucocorticoids, many endogenous peptides are secreted, including opioids (Munck \& NárayFejes-Tóth, 1994). Therefore, as opioids have a documented role in ischemic preconditioning (Frässdorf et al., 2005), it is possible that hydrocortisone exerts its cardioprotective effects in ischemic preconditioning from an increased release of these mediators.

Preliminary studies have shown a direct correlation between plasma levels of CK and CK$\mathrm{MB}$ and the severity of myocardial tissue damage and myocardial infarction (Celik et al., 2004). Giomarelli et al. (2003) concluded that preventive administration of corticosteroids, by reducing proinflammatory cytokine release and increasing blood IL-10 levels, may provide a better degree of myocardial protection. In our study, we did not determine plasma levels of cytokines, but we did measure the plasma levels of cTnT, which is more accurate than

CK-MB for assessing myocardial infarction. As a result, we can propose that the protective effect of hydrocortisone in our study may be related to a decreasing plasma level of proinflammatory cytokines and/or an increase in anti-inflammatory ones. Further studies are needed to clarify the exact role of cytokines in the protective mechanism afforded by hydrocortisone.

In summary, we have shown that hydrocortisone has cardioprotective effects when injected before the onset of a myocardial infarction. In addition, we have proposed for the first time that endogenous hydrocortisone may play a role in the ischemic preconditioning phenomenon. Therefore, it is recommended that more studies be designed to determine the exact mechanism of endogenous hydrocortisone in ischemic preconditioning, especially in relation to mineralocorticoid action, free radical scavenging and cytokine modulation. 


\section{ACKNOWLEDGMENTS.}

The authors are appreciative of the financial support provided by the deputy of research, Golestan University of Medical Sciences for this research project No. G.P.35.2212. This article is written based on the results of thesis No.407, submitted to Golestan University of Medical Sciences in fulfillment of the requirements of Doctor of Medicine, of Mr.Ali Davarian. We are also indebted to Dr. Ahmadi, Dr. Rabbani, Mr. Rahim Davarian and Mrs. Shirinbeik Mohajer for their leading suggestions.

DAVARIAN, A.; KHORI, V. \& NAYEBPOUR, M. Efectos cardioprotectores de la hidrocortisona exógena y endógena en el modelo isquemia-reperfusión de conejo. Int. J. Morphol., 28(3):653-658, 2010.

RESUMEN: La reducción del tamaño del infarto en el infarto agudo de miocardio es una de las metas más importantes que impulsan la investigación y el desarrollo de nuevos fármacos. Durante las dos últimas décadas, muchos estudios clínicos han encontrado efectos cardioprotectores de los corticosteroides, pero su papel exacto en el preacondicionamiento isquémico sigue siendo cuestionable. El objetivo del presente estudio fue determinar los efectos protectores de succinato sódico de hidrocortisona en el preacondicionamiento del miocardio en el corazón de conejo. Veinticuatro conejos neozelandeses machos fueron divididos al azar en cuatro grupos : 1) control, 2) infarto, 3) preacondicionamiento isquémico (PI) y 4) Hidrocortisona (HYD). El grupo HYD recibió $50 \mathrm{mg} / \mathrm{kg}$ de hidrocortisona 45 minutos antes de la isquemia mayor. Los niveles séricos de troponina cardíaca T (cTNT) y cortisol se midieron antes y después de los protocolos. Se utilizó la tinción cloruro de trifenil-tetrazolio para determinar el área infartada. En el presente estudio, la hidrocortisona exógena disminuyó el tamaño del infarto en un 53\% en comparación con el grupo de infarto. Los niveles séricos de cortisol se incrementaron en los grupos IP y HYD, siendo significativa en el grupo de HYD $(\mathrm{p}<0,01)$. Un aumento en el nivel cortisol se asoció con la disminución del tamaño del infarto y la cTNT en los grupos IP y HYD ( $>$ > 0,01). En conclusión, hemos demostrado la hidrocortisona tiene efectos cardioprotectores cuando se inyecta antes de la aparición del infarto al miocardio. Además, hemos propuesto, por primera vez que la hidrocortisona endógena puede jugar un papel en los fenómenos de preacondicionamiento isquémico.

PALABRAS ClAVE: Hidrocortisona; Tamaño del infarto; Modelo de isquemia-reperfusión; Preacondicionamiento isquémico; Cortisol sérico.

\section{REFERENCES}

Armstrong, S. C.; Shivell, L. C. \& Ganote, C. E. Sarcolemmal blebs and osmotic fragility as correlates of irreversible ischemic injury in preconditioned isolated rabbit cardiomyocytes. J. Mol. Cell. Cardiol., 33:149-60, 2001.

Barzilai, D.; Plavnick, J.; Hazani, A.; Einath, R.; Kleinhaus, N. \& Kanter, Y. Use of hydrocortisone in the treatment oacute myocardial infarction: Summary of a clinical trial in 446 patients. Chest, 61:488-91, 1972.

Bourbon, A.; Vionnet, M.; Leprince, P.; Vaissier, E.; Copeland, J.; McDonagh, P.; Debré, P. \& Gandjbakhch, I. The effect of methylprednisolone treatment on the cardiopulmonary bypassinduced systemic inflammatory response. Eur. J. Cardiothorac. Surg., 26:932-8, 2004.

Cannon, R. O. 3rd.; Rodríguez, E. R.; Speir, E.; Yamaguchi, M.; Butany, J.; McManus, B. M.; Bolli, R. \& Ferrans, V. J. Effect of ibuprofen on the healing phase of experimental myocardial infarction in the rat. Am. J. Cardiol., 155:1609-13, 1985.

Celik , J. B.; Gormus, N.; Okesli, S.; Gormus, Z. I. \& Solak, H. Methylprednisolone prevents inflammatory reaction occurring during cardiopulmonary bypass: effects on TNF-alpha, IL-6, IL-8, IL-10. Perfusion, 19:185-91, 2004.

Eisen, A.; Fisman, E. Z.; Rubenfire, M.; Freimark, D.; McKechnie, R.; Tenenbaum, A.; Motro, M. \& Adler, Y. Ischemic preconditioning: nearly two decades of research. A comprehensive review. Atherosclerosis, 172:201-10, 2004.

Enc, Y.; Karaca, P.; Ayoglu, U.; Camur, G.; Kurc, E. \& Cicek, S. The acute cardioprotective effect of glucocorticoids in myocardial ischemia-reperfusion injury occurring during cardiopulmonary bypass. Heart Vessels, 21:152-6, 2006.

Fillinger, M. P.; Rassias, A. J.; Guyre, P. M.; Sanders, J. H.; Beach, M.; Pahl, J.; Watson, R. B.; Whalen, P. K.; Yeo, K. T. \& Yeager, M. P. Glucocorticoid Effects on the Inflammatory and Clinical Responses to Cardiac Surgery. J. Cardiothorac. Vasc. Anesth., 16:163-9, 2002.

Frässdorf, J.; Weber, N. C.; Obal, D.; Toma, O.; Müllenheim, J.; Kojda, G.; Preckel, B. \& Schlack, W. Morphine induces late cardioprotection in rat hearts in vivo: the involvement of opioid receptors and nuclear transcription factor kappaB. Anesth. Analg., 101:934-41, 2005.

Fu, Y.; Wang, Z.; Chen, W. L.; Moore, P. K. \& Zhu, Y. Z. Cardioprotective effects of nitric oxide-aspirin in myocardial ischemia-reperfused rats. Am. J. Physiol. Heart Circ. Physiol., 293:H1545-52, 2007.

Giomarelli, P.; Scoletta, S.; Borelli, E. \& Biagioli, B. Myocardial and lung injury after cardiopulmonary bypass:role of interleukin (IL)-10. Ann. Thorac. Surg., 76:117-23, 2003. 
Giugliano, G. R.; Giugliano, R. P.; Gibson, C. M. \& Kuntz, R. E. Meta-analysis of corticosteroid treatment in acute myocardial infarction. Am. J. Cardiol., 91:1055-9, 2003.

Gómez-Sánchez, C. E. \& Gómez-Sánchez, E. P. Editorial: Cardiac steroidogenesis--new sites of synthesis, or much ado about nothing? J. Clin. Endocr. Metab., 86:511820, 2001.

Gross, E. R.; Hsu, A. K. \& Gross, G. J. Acute aspirin treatment abolishes, whereas acute ibuprofen treatment enhances morphine-induced cardioprotection: Role of 12-lipoxygenase. J. Pharmacol. Exp. Ther., 310:185-91, 2004.

Hafezi-Moghadam, A.; Simoncini, T.; Yang, Z.; Limbourg, F. P.; Plumier, J. C.; Rebsamen, M. C.; Hsieh, C. M.; Chui, D. S.; Thomas, K. L.; Prorock, A. J.; Laubach, V. E.; Moskowitz, M. A.; French, B. A.; Ley, K. \& Liao, J. K. Acute cardiovascular protective effects of corticosteroids are mediated by non-transcriptional activation of endothelial nitric oxide synthase. Nat. Med., 8:473-8, 2002.

Hepper, N. G.; Pruitt, R. D.; Donald, D. E. \& Edwards, J. E. The effect of cortisone on experimentally produced myocardial infarcts. Circulation, 11:742-8, 1955.

Johnson, A. S.; Scheinberg, S. R.; Gerisch, R. A. \& Saltzestein, H. C. Effect of cortisone on the size of experimentally produced myocardial. Circulation, 7:224-8, 1953.

Kilger, E.; Weis, F.; Briegel, J.; Frey, L.; Goetz, A. E.; Reuter, D.; Nagy, A.; Schuetz, A.; Lamm, P.; Knoll, A. \& Peter, K. Stress doses of hydrocortisone reduce severe systemic inflammatory response syndrome and improve early outcome in a risk group of patients after cardiac surgery. Crit. Care Med., 31:1068-74, 2003.

Libby, P.; Maroko, P. R.; Bloor, C. M.; Sobei, B. E. \& Braunwald, E. Reduction of experimental myocardial infarct size by corticosteroid administration. J. Clin. Invest., 52:599-607, 1973.

Lochner, A.; Genade, S.; Tromp, E.; Opie, L.; Moolman, J.; Thomas, S. \& Podzuweit, T. Role of cyclic nucleotide phosphodiesterases in ischemic preconditioning. Mol. Cell Biochem., 186:169-75, 1998.

Lochner, A.; Marais, E.; Du Toit, E. \& Moolman, J. Nitric oxide triggers classic ischemic preconditioning. Ann. NY Acad. Sci., 962:402-14, 2002.
Maclean, D.; Fishbein, M. C.; Braunwald, E. \& Maroko, P. R. Long-Term preservation of ischemic myocardium after experimental coronary artery occlusion. J. Clin. Investig., 61:541-51, 1978.

Munck, A. \& Náray-Fejes-Tóth, A. Glucocorticoids and stress: Permissive and suppressive actions. Ann. NY Acad. Sci., 746:115-30, 1994.

Park, J. L. \& Lucchesi, B. R. Mechanisms of myocardial reperfusion injury. Ann. Thorac. Surg., 68:1905-12, 1999.

Sapolsky, R. M.; Romero, L. M. \& Munck, A. U. How do glucocorticoids influence stress responses? Integrating permissive, suppressive, stimulatory, and preparative actions. Endocr. Rev., 21:55-89, 2000.

Takahashi, T.; Takeyoshi, I.; Hasegawa, Y.; Koyano, T.; Yamagishi, T.; Ohshima, K.; Ishikawa, S.; Ohtaki, A.; Matsumoto, K. \& Morishita, Y. Lazaroid U-74389G ameliorates ischemia reperfusion injury in canine hearts: A histologic study. Transplant. Proc., 30:3334-6, 1998.

Villa, R. F. \& Gorini, A. Pharmacology of lazaroids and brain energy metabolism: A review. Pharmacol. Rev., 49:99136, 1997.

Werns, S. W. \& Lucchesi, B. R. Myocardial ischemia and reperfusion: the role of oxygen radicals in tissue injury. Cardiovasc. Drugs Ther., 2:761-9, 1989.

White, P. C. Aldosterone: direct effects on and production by the heart. J. Clin. Endocr. Metab., 88:2376-83, 2003.

Zipes, D. P. \& Braunwald, E. Braunwald's Heart Disease: a Textbook of Cardiovascular Medicine. $7^{\text {th }}$ Edn. Philadelphia, Elsevier, 2005. pp.1147-54.

Correspondence to:

Dr. Vahid Khori

Golestan Cardiovascular Research Centre

Faculty of Medicine

Golestan University of Medical Sciences, Gorgan IRAN

Tel: +981715520200

Email: alidavarian@gmail.com

Received: 14-11-2010

Accepted: 12-03-2010 